\title{
Acadiensis
}

Journal of the History of the Atlantic Region

Revue d'histoire de la région Atlantique

\section{“Gilded Misery”}

The Robie Women in Loyalist Exile and Repatriation, 1775-1790

\section{G. Patrick O’Brien}

Volume 49, numéro 1, printemps 2020

URI : https://id.erudit.org/iderudit/1072250ar

Aller au sommaire du numéro

\section{Éditeur(s)}

Department of History at the University of New Brunswick

ISSN

0044-5851 (imprimé)

1712-7432 (numérique)

Découvrir la revue

Citer cet article

O’Brien, G. (2020). “Gilded Misery”: The Robie Women in Loyalist Exile and Repatriation, 1775-1790. Acadiensis, 49(1), 39-68.

\section{Résumé de l'article}

Forcés de fuir Marblehead, au Massachusetts, à la fin d'avril 1775, Thomas Robie, sa femme, Mary Bradstreet Robie, et leurs quatre enfants furent parmi les premiers Loyalistes à débarquer en Nouvelle-Écosse. L'arrivée de milliers d’autres Loyalistes en 1783 entraîna des difficultés généralisées dans la région, mais la souffrance collective fournit également à Mary Bradstreet Robie et à ses deux filles l'occasion d'apporter une contribution à la communauté loyaliste et d'affirmer leur volonté au sein de la famille. La présente étude de la famille Robie démontre que les femmes loyalistes n'étaient pas simplement une source de soutien au foyer, pas plus qu'elles n'étaient résignées à s'exiler en suivant passivement les maris et les pères de famille. 


\title{
"Gilded Misery": \\ The Robie Women in Loyalist Exile and Repatriation, 1775-1790
}

\author{
G. PATRICK O'BRIEN
}

\begin{abstract}
Forcés de fuir Marblehead, au Massachusetts, à la fin d'avril 1775, Thomas Robie, sa femme, Mary Bradstreet Robie, et leurs quatre enfants furent parmi les premiers Loyalistes à débarquer en Nouvelle-Écosse. L'arrivée de milliers d'autres Loyalistes en 1783 entraîna des difficultés généralisées dans la région, mais la souffrance collective fournit également à Mary Bradstreet Robie et à ses deux filles l'occasion d'apporter une contribution à la communauté loyaliste et d'affirmer leur volonté au sein de la famille. La présente étude de la famille Robie démontre que les femmes loyalistes n'étaient pas simplement une source de soutien au foyer, pas plus qu'elles n'étaient résignées à s'exiler en suivant passivement les maris et les pères de famille.
\end{abstract}

Forced to flee Marblehead, Massachusetts, in late April 1775, Thomas Robie, his wife Mary Bradstreet Robie, and their four children were among the earliest Loyalist refugees to land in Nova Scotia. The arrival of thousands more Loyalists in 1783 brought widespread hardship to the region, but the collective suffering also provided Mary Bradstreet Robie and her two daughters the opportunity to contribute to the Loyalist community and assert their will within the family. This study of the Robie family demonstrates that Loyalist women were not simply domestic figures of support nor were they resigned to exile as passive followers of husbands and fathers.

ON THE AFTERNOON OF 4 OCTOBER 1783, 19-year-old Mary Robie and her younger sister Mehetable - or "Hetty" as her family and friends affectionately knew her - made the short walk from their home on Granville Street to Halifax's Old Burying Ground. Although the sisters were travelling to a funeral, Mary thought more about the deteriorating weather conditions than about the somber event she was attending. "As it was a person we had no regard for nor had ever seen," she explained, "we imagined that we should be unaffected." As she watched the corpse being lowered into the grave, however, Robie acknowledged that the "gloomy awful scene" left her "exceedingly affected." She and her sister spent that evening with their mother and aunt at the home of one of their neighbors. While such visits were not uncommon, Robie noted that after attending the funeral, time spent with her family and friends helped 
"dispel all the gloomy thoughts which the awful scene had given birth to." Like so many others, the Robie sisters found a reprieve from the hardships of daily life through the comfort of family.

The pages of Mary Robie's diary, which she kept almost daily from May 1783 until June of the following year, provide an intimate glimpse into the rhythm of daily life in Halifax. ${ }^{2}$ The daughter of a prosperous hardware merchant, who had fled Massachusetts and arrived in Halifax during the early days of the Revolution, Robie used her diary to record her daily routine. Perhaps hoping to echo her mother's opinion that Halifax was "a dumb and stupid place, [which] furnishes no topick [sic] either for conversation or writing," the teenage Robie often grumbled about the tedium of her usual day. ${ }^{3}$ In one entry, she sarcastically explained that mornings were typically spent entertaining friends with "the most interesting discourse on fashionable caps and gowns" and talking "scandal or fashions." Afternoons were for little more than "tea, cards, supper, and to bed" only to "rise tomorrow and do just the same." "What little variety there is in our lives," she complained. ${ }^{4}$

Robie's diary entries reveal that she lived a life of relative privilege, where social calls and leisurely activity filled her days. But equally unmistakable is her description of the emotional toll of exile and the constant struggle she faced as a refugee. On a personal level Robie lamented the disorder of Loyalist

1 Mary Robie, diary, 4 October 1783, Robie-Sewall Family Papers, Massachusetts Historical Society (MHS), Boston. This work was partially supported by a SPARC Graduate Research Grant from the office of the vice-president for research at the University of South Carolina and a W.B.H. Dowse Fellowship from the Massachusetts Historical Society. I would like to thank the anonymous reviewers from Acadiensis for their constructive criticisms and the members of the Atlantic History Reading Group at the University of South Carolina for their collective feedback over many drafts of this article.

2 In this article, I use Mary Robie's diary entries to document one Loyalist family's routine - that is, their regular activities and interaction with the broader community. But as Robie also used her diary to record her inner thoughts, I also use her entries to gain insight into how she understood and felt about her family's situation as exiles. As Susan M. Stabile explains in her work on transatlantic diaries and commonplace books, "The commonplace book and the diary were the cabinets for preservation and display." Although Robie's journal recorded everyday events, in diarying she was also performing what she considered to be an important duty of a refined woman in the late 18th century. Taken as a whole, Robie's diary provides a valuable glimpse both into the inner workings of revolutionary Halifax and one refugee's personal experience as an exile; see Stabile, "Female Curiosities: The Transatlantic Female Commonplace Book," in Reading Women: Literacy, Authorship, and Culture in the Atlantic World, 1500-1800, ed. Heidi Brayman Hackel and Catherine E. Kelly (Philadelphia: University of Pennsylvania Press, 2009), 221.

3 Mary Bradstreet Robie to Thomas Robie, 9 January 1776, Robie-Sewall Family Papers, MHS.

4 Mary Robie, diary, 22 May 1783, Robie-Sewall Family Papers, MHS. 
Halifax, especially the constant comings and goings of friends and family as transient revolutionary refugees continually moved across the British Atlantic in search of opportunity. "There is something so sad and so solemn in bidding one adieu, perhaps forever," she wrote after saying goodbye to a young woman she had come to know during the girl's two-year stay in Halifax. Describing how her and her sister felt after learning their close family friends would be leaving Halifax for London, Robie explained "Hetty squeezed my hand, we could neither of us speak."' But the distress of exile was not simply personal. Robie also used her diary to record the broader, inescapable anguish of Loyalist Halifax that plagued all members of society, even those whose status protected them from the worst poverty and physical suffering. "I have been a great deal engaged in some painful and melancholy scenes, which have almost effaced the pleasing ones," she wrote of the overwhelming despair of Halifax in June 1784. "If I look round me, what thousands may I see more wretched than myself."

How did refugee women respond to the often-overwhelming sadness of revolutionary exile? While previous scholars have suggested that in the face of seemingly unrelenting sadness, women became "domestic creatures" of support whose "personal world did not extend beyond the front door," this article uses the exile experience of the Robie family to demonstrate that women were not always "stoic, long-suffering, self-sacrificial, female[s] who bore [their] unhappiness bravely." 7 To the contrary, in settlements where grief abounded, compassionate and emotional women became central figures of support in the community and could also take on leading roles within the home. Aware of the collective Loyalist suffering, the Robie women employed traditional acts of familial support in public and helped build a sense of community among diverse refugees. Closer to home, Mary Bradstreet Robie - whom I distinguish from her eldest daughter, also named Mary, by using her maiden name argued with her more stubborn husband that the family's well-being, as well as her own happiness, necessitated a return to New England after the war. Rather

5 Mary Robie, diary, 23 May 1783 and 14 September 1783, Robie-Sewall Family Papers, MHS.

6 Mary Robie, diary, 4-5 June 1784, Robie-Sewall Family Papers, MHS.

7 On women as "domestic creatures," see Anne Gorman Condon, "The Family in Exile: Loyalist Social Values After the Revolution," in Intimate Relations: Family and Community in Planter Nova Scotia, 1759-1800, ed. Margret Conrad (Fredericton: Acadiensis Press, 1997), 48. On the idea that the Loyalist women were stoic observers, see Beatrice Ross Buszek, "'By fortune wounded': Loyalist Women in Nova Scotia," Nova Scotia Historical Review 7, no. 2 (1987): 59-60 and Beatrice Spence Ross, "Adaptation in Exile: Loyalist Women in Nova Scotia After the American Revolution" (PhD diss. in history, Cornell University, 1981), 164. 
than stoically face the misery of exile, the public and private roles of the Robies demonstrate that Loyalist women could use suffering to their advantage.

This article examines how Loyalist women responded to the hardships of exile and makes two claims. First, in Loyalist settlements where suffering abounded, women took on public roles of support that became the basis for an emotional community. ${ }^{8}$ As Keith Grant notes, "Early modern Nova Scotians did things with their emotions"; in Loyalist Halifax, women like the Robies recognized that their responses to widespread hardship carried tremendous emotional power. 9 The "lived experience" of revolution and subsequent exile, especially the destruction of social networks and the widespread poverty of the refugee community, caused men and women of every class in Loyalist Halifax to feel a heightened sense of fellow feeling toward others. ${ }^{10}$ Although Bostonian Loyalist Mather Byles Jr. and the former Royal Governor of South Carolina Lord Charles Montagu shared little in common besides their fate as refugees, for example, when Byles learned of Montagu's death in February 1784 he could not help but feel shaken by the former governor's precipitous fall from power. He felt pity for Montagu and, as a fellow member of the Loyalist elite, he also

8 As Barbra Rosenwein explains, "An emotional community is a group in which people have a common stake, interests, values, and goals"; see Rosenwein, Emotional Communities in the Early Middle Ages (Ithaca, NY: Cornell University Press, 2006), 24. She further defines an "emotional community" as "precisely the same as social communities - families, neighborhoods, parliaments, guilds, monasteries, parish church memberships - [connected through] systems of feeling: what these communities (and the individuals within them) define and assess as valuable or harmful to them; the evaluations that they make about others' emotions; the nature of the affective bonds between people that they recognize; and the modes of emotional expression that they expect, encourage, tolerate, and deplore"; see Rosenwein, "Worrying About Emotions in History," American Historical Review 107, no. 3 (June 2002): 842. For a background in the history of emotions, see Peter N. Stearns with Carol Z. Stearns, "Emotionology: Clarifying the History of Emotions and Emotional Standards," American Historical Review 90, no. 4 (October 1985): 813-36 and Rom Harré, ed., The Social Construction of Emotions (Oxford: Oxford University Press, 1986).

9 Keith S. Grant, "Enthusiasm and Loyalty: Emotions, Religion, and Society in British North America" (PhD diss. in history, University of New Brunswick, 2017), 335 (emphasis his own). This is not to suggest that suffering was the sole Loyalist emotion; rather, Loyalist women used shared suffering because societal norms dictated that women were sensitive to the hardships of others. On the diversity of Loyalist emotions, see Grant, "Enthusiasm and Loyalty," 321-35. In addition, it should be noted that Loyalist women's empathy had real racial limits. Women did not feel compelled to act empathically toward thousands of Black refugees whose suffering was worse than their white counterparts. For the most comprehensive study of Black Nova Scotia in the Revolutionary Era, see Harvey Amani Whitfield, "Black Loyalists and Black Slaves in Maritime Canada," History Compass 5/6 (October 2007): 1980-97.

10 For the relationship between revolutions, personal autonomy, and sensitivity toward others, see Lynn Hunt, Inventing Human Rights: A History (New York: W.W. Norton, 2007). 
worried that he too might die alone without fanfare "in a little hut in the woods of Nova Scotia." ${ }^{11}$

But Byles's feelings were limited to his private writings. Publicly, he and other Loyalist men were determined to project the confidence of fervent British patriots. In contrast, women were expected to be more aware of, and sympathetic to, the suffering of others. ${ }^{12}$ When the Robies visited newly arrived strangers, hosted a number of itinerant families at their home, and wept at the funerals of young men and women they had never met, they shared the suffering of others. Instead of an isolating feeling that pushed women into their homes, shared misery became the basis for a collective system of feeling. ${ }^{13}$ While previous scholars have explained women's public practices as little more than an a reimaging of more exciting pre-revolutionary lives, studying the Robie women suggests that Loyalist wives and daughters used the common suffering to recreate bonds that had been lost in exile and establish a body of "elective-kin" among those who shared little else except the emotional toll of resettlement. ${ }^{14}$

The Robie women also used the ever-present despair of Loyalist Halifax to achieve their own objectives within the home. Despite the previous assertions that women "held out little hope of returning to America," matriarch Mary Bradstreet Robie was eager to bring her family back to New England following the peace of 1783 and used her unhappiness to make it happen. ${ }^{15}$ Returning

11 Mather Byles II to Kitty Byles, 10 February 1784, Byles Family Papers, Nova Scotia Archives (NSA), Halifax.

12 On the cultural expectations for women, see Leora Auslander, Cultural Revolutions: Everyday Life and Politics in Britain, North America and France (Berkeley: University of California Press, 2009), 8 and Nicole Eustace, "Emotion and Political Change," in Doing Emotions History, ed. Susan J. Matt and Peter N. Stearns (Urbana-Champagne, IL: University of Illinois Press, 2014), 174. On late-18th-century women's particular attention to the feelings of others, see Sarah Knott, Sensibility and the American Revolution (Chapel Hill, NC: University of North Carolina Press, 2009).

13 As cultural scholar Uta Stagier notes in her work on the European Union, "Emotions provide us with a sense of what matters, what is of concern to us as individuals." These concerns also extended to broader communities, where they help form the backbone of society; see Stagier, "The Heart of the Matter: Emotional Politics in the New Europe," in Brexit and Beyond: Rethinking the Futures of Europe, ed. Benjamin Martill and Uta Stagier (London: University College London Press, 2018), 232.

14 On the reimagining of colonial lives before the Revolution, see Condon, "Family in Exile," in Conrad, Intimate Relations. For Loyalists and communities of "elective-kin," see Bonnie Huskins, "'Remarks and Rough Memorandums': Social Sets, Sociability, and Community in the Journal of William Booth, Shelburne, 1787 and 1789," Journal of the Royal Nova Scotia Historical Society 13 (2010): 106.

15 Condon, "Family in Exile," in Conrad, Intimate Relations, 47; Janice Potter-MacKinnon, While the Women Only Wept: Loyalist Refugee Women in Eastern Ontario (Montreal and Kingston: McGill-Queen's University Press, 1993), xv. 
briefly to her native Massachusetts in the summer of 1784 to escape diseaseridden Halifax and care for her sickly newborn daughter, Robie became only further convinced that the family would never be as happy in Nova Scotia as they could be in Massachusetts. During the next five years, she began a sustained appeal to her husband that they should repatriate. In her plea, Robie emphasized both her duty to protect her children and her emotional longing for home. Despite her efforts, her family's connections to Nova Scotia grew only stronger after her return to Halifax in 1784 . Sensing the need for more concrete connections, Robie facilitated a marriage between her eldest daughter and the promising young Boston merchant Joseph Sewall during another trip back to Marblehead in 1788. In the spring of 1789, with her family's New England connection secure, she demonstrated the power of her influence in a letter she sent back to her husband in Halifax. "If you expect ever to see me again," she asserted, "you must come here." Her husband landed in back in New England the following year, forever separating branches of the family between two nations. ${ }^{16}$

In tracing the role of the Robie women in Loyalist Halifax, this article also contributes to many interconnected historiographies. As the Robie sisters' service at the stranger's funeral exhibits, women were an integral part of burial practices and refugees adapted mourning rituals to fit their situation. ${ }^{17}$ The Robie women's attention to other refugees' hardship and grief suggests new ways historians of the Loyalist diaspora and American Revolution could consider women's agency in regards to the war, allegiances, and exile. The family's return to Massachusetts not only suggests further study is needed into the return of the American Loyalists, but it also demonstrates how wives and daughters acted as facilitators of repatriation and sheds light on how marriage could be used to promote reconciliation after the Revolution. ${ }^{18}$

16 Mary Bradstreet Robie to Thomas Robie, 21 May 1789, Robie-Sewall Family Papers, MHS.

17 On burial practices in Nova Scotia, see Gillian Poulter, "What's Traditional about 'the traditional funeral'? Funeral Rituals and the Evolution of the Funeral Industry in Nova Scotia," Journal of the Canadian Historical Association 22, no. 1 (2011): 133-59. For similar examples of deathways taking on new significance in challenging situations, see Erik R. Seeman, Death in the New World: Cross-Cultural Encounters, 1492-1800 (Philadelphia: University of Pennsylvania Press, 2010), chap. 8.

18 For studies on the return and reintegration of the American Loyalists, see Stephanie Kermes, "'I wish for nothing more ardently upon earth, than to see my friends and country again': The Return of Massachusetts Loyalists," Historical Journal of Massachusetts 30, no. 1 (Winter 2002): 30-49; David Edward Maas, "The Return of the Massachusetts Loyalists" (PhD diss. in history, University of Wisconsin, 1972); Rebecca Brannon, From Revolution to Reunion: The Reintegration of the South Carolina Loyalists (Columbia, 


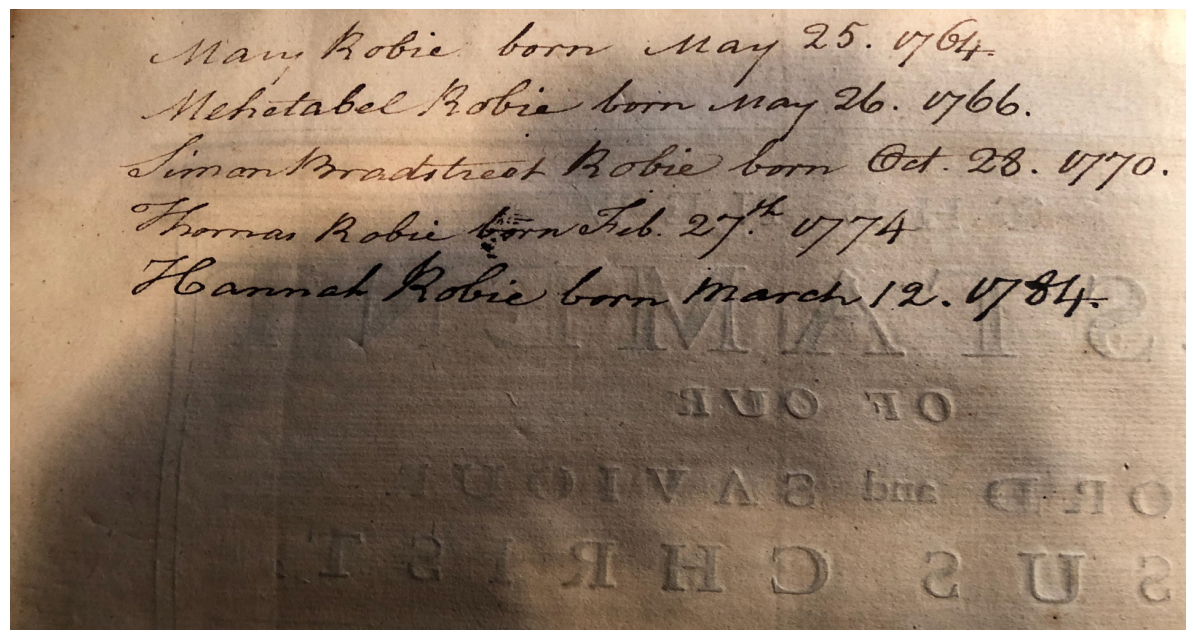

Figure 1 - The names of the Robie children inscribed by Mary Bradstreet Robie in her grandfather's Book of Common Prayer, which he purchased in 1744 and bequeathed to her upon his death in late 1771. The inclusion of Hannah's birth in 1784 suggests the book was one of the few items Mary Bradstreet Robie was able to take with her upon leaving Marblehead in 1775.

Source: Courtesy of private collector Matthew Schweitzer.

\section{"Fellow feeling"19 and community}

The Robie family's last few years in Massachusetts were tumultuous. A vendor of imported British goods in the affluent North Shore town of Marblehead, Thomas Robie's business struggled in the early days of the Massachusetts boycott. Throughout 1769, Samuel Hall used his weekly newspaper, the Essex Gazette, to identify and publicly condemn merchants who failed to comply with the non-importation agreements. In December of that year, Hall named Robie, alongside three others of Marblehead, as purveyors who continued to import and store British-made products. He urged the town's patriots to recognize that these men did "sordidly prefer their private interest to the public Good." Robie published a reply weeks later; however, few of Hall's subscribers were sympathetic to his defense. ${ }^{20}$ Robie again enflamed the patriot majority

SC: University of South Carolina Press, 2016); and Aaron N. Coleman, "Loyalists in War, Americans in Peace, 1775-1800" (PhD diss. in history, University of Kentucky, 2008).

19 Colonists during the 17th and 18th centuries understood "fellow feeling" to mean, as Abram C. Van Engen notes, "identification with another's experience, often invoking an imaginative transfer of oneself into the place of another"; see Van Engen, Sympathetic Puritans: Calvinist Fellow Feeling in Early New England (New York: Oxford University Press, 2015), 15.

20 Essex Gazette (Boston), 12-19 December 1769. On Samuel Hall and his newspaper during the colonial crisis, see Benjamin F. Arrington ed., Municipal History of Essex County in 
of Marblehead in 1773 when he had himself and his family inoculated against smallpox, a decision many radicals believed was a part of a Tory conspiracy to spread the disease among the town's inhabitants. ${ }^{21}$ The final straw came in May 1774 when Robie signed his name, alongside other prominent merchants and politicians of the Boston area, in a letter expressing support for the despised governor Thomas Hutchinson. ${ }^{22}$ Following his public endorsement of Hutchinson, Robie joined the ranks of other prominent Tories and hostilities against him and his family intensified.

Attacks against ardent and perceived British sympathizers in Massachusetts became increasingly violent in the late summer months of 1774. On 1 September 1774, Thomas's cousin and Massachusetts Attorney General Jonathan Sewall returned from court in Boston to his family's Cambridge residence and found a patriot mob had smashed the windows and terrified his wife and children. Sewall removed to Boston for his family's safety, and he advised his cousin to do the same. ${ }^{23}$ Facing increasing pressure from his creditors, Robie mortgaged the family's home for $£ 800$ in late $1774 \cdot{ }^{24} \mathrm{He}$ drew up his last will and testament on 22 March $1775 .{ }^{25} \mathrm{~A}$ month later, the people of Marblehead ransacked Robie's business much like they had Sewall's home. Robie took his family first to his sister Mehitable Higginson's home in neighbouring Salem, but fearful of continuing retribution the Robies - including Thomas, his wife Mary Bradstreet Robie, daughters Mary (age 11) and Hetty (age 9), and sons Simon Bradstreet (age 5) and Thomas (barely 1 year) as well as Higginson and her ten-year-old daughter - fled north to Nova Scotia on 2 May $1775 .{ }^{26}$

Massachusetts, tercentenary ed. (New York: Lewis Historical Publishing, 1922), 1:732-3. For Robie's reply to Hall's criticism, see Jonathan Sewall to Thomas Robie, 10 January 1770, Robie-Sewall Family Papers, MHS.

21 On the reaction to smallpox inoculations in New England, see Andrew M. Wehrman, "The Siege of 'Castle Pox': A Medical Revolution in Marblehead, Massachusetts, 1764-1777," New England Quarterly 82, no. 3 (September 2009): 385-429. On Thomas Robie's defense of Dr. James Latham, the physician who administered the inoculations, see Essex Gazette, 8-15 March 1775.

22 On Thomas Robie's allegiance to Hutchinson, see "Address of the Inhabitants of Marblehead to Gov. Hutchinson, 25 May 1774," in James Henry Stark, The Loyalists of Massachusetts and the Other Side of the American Revolution (Salem: Salem Press Company, 1910), 127-8.

23 Carol Berkin, Jonathan Sewall: Odyssey of an American Loyalist (New York: Columbia University Press, 1974).

24 Thomas Robie to Ward Chipman (unfinished letter), 7 December 1786, Robie-Sewall Family Papers, MHS.

25 Thomas Robie, "Will and Testament signed by William Pychon, Catherine Pychon, and William Pychon Jr.," 22 March 1775, Robie-Sewall Family Papers, MHS. Jonathan Sewall to Thomas Robie, 7 June 1775, Robie-Sewall Family Papers, MHS. 
The family was among the earliest Loyalist arrivals to Halifax and, as such, enjoyed unique advantages over refugees who arrived in the later war years. ${ }^{27}$ Most importantly, as an early arrival, Thomas Robie was able to establish himself as a hardware merchant and profit from the tremendous increase of capital that followed the Royal Navy to Halifax during the American Revolution. ${ }^{28} \mathrm{He}$ also profited from supplying later refugees. By the early $178 \mathrm{os}$, Thomas' financial success allowed him to join at least the outer ranks of Halifax's mercantile bourgeoisie. As a sign of his family's growing wealth and importance, on 22 April 1780 or almost five years after the family's arrival, Thomas purchased a lot near the waterfront on the bustling Granville Street from Peter McNabb for $£ 345$, and from his new home Robie continued to run his hardware business. ${ }^{29}$

The Robie family also acted as an advance guard of New England refugees in Nova Scotia. Both Thomas and his wife maintained frequent correspondence with friends and family held up in Boston with General Gage and his army through March 1776. In a series of letters exchanged with Sewall, Robie kept his cousin informed of life in Halifax and Sewall gave Robie an account of Boston under siege. Circumstances were dire in both cities. "For a month past you met as many dead folks as live ones," Sewall recounted of the hunger, inflation, and disease that plagued Boston during Washington's land blockade..$^{30}$ Robie's news from Halifax was little better. He described a series of illnesses that afflicted

27 Roughly 344 Tories fled Massachusetts during the summer month of 1775 . Some of these early refugees chose to settle in nearby Nova Scotia and wait out the troubles, while others continued on to England; see Kermes, "I wish for nothing more ardently upon earth, than to see my friends'" and Maas, "Return of the Massachusetts Loyalists."

28 For one of the best accounts of the Halifax economy between 1749 and the end of the Revolution, see Lewis R. Fischer, "Revolution Without Independence: The Canadian Colonies, 1749-1775," in The Economy of Early America: The Revolutionary Period, 1763-1790, ed. Ronald Hoffman et al. (Charlottesville, VA: University of Virginia Press, 1988), 88125. Halifax was home to a small but powerful mercantile elite who had arrived shortly after the capital's founding in 1749, but the seemingly endless stream of sailors, soldiers, and refugees that came to Halifax in the decade after 1775 created an opportunity for Revolutionary-era arrivals like Robie. On the role of the British navy in the early years of Halifax, see Julian Gwyn, Frigates and Foremasts: The North American Squadron in Nova Scotia Waters (Vancouver: UBC Press, 2003). The merchant-bourgeois class began as early as 1752, and although its importance to the history of Halifax and Nova Scotia has been the subject of debate it was no doubt impactful on the development of the region; see James Muir, "The Fight for Bourgeois Law in Halifax, Nova Scotia, 1749-1753," Social History 69, no. 98 (May 2016): 1-25 and Donald F. Chard, "Capitalists, Merchants, and Manufacturers in Early Nova Scotia, 1769-1791: The Tangled Affairs of John Avery, James Creighton, John Albro, and Joseph Fairbanks," in Conrad, Intimate Relations, 190-212.

29 Indenture Peter McNabb and Thomas Robie, 22 April 1780, Robie-Sewall Family Papers, MHS.

30 Jonathan Sewall to Thomas Robie, 15 July 1775, Robie-Sewall Family Papers, MHS. 
the earliest arrivals to Halifax. Sewall had planned to take up his position as judge of the Vice Admiralty Court in Halifax, but news of a smallpox epidemic in Halifax gave him second thoughts. He ultimately decided to sail for England in the late summer of 1775, where he believed he could use his political connections to secure a better government position in Nova Scotia. He encouraged his cousin to join him, and Robie left Halifax, and his family, sometime in the early fall of $1775 .{ }^{31}$ Knowing the two would be reunited in London, Sewall's outlook on the war improved dramatically. Sewall wrote assuredly to Halifax, "Cheer up Robie, I think I see Daylight tho' it has been a long dark stormy night - I begin to hope the storm has almost spent itself."32

But left alone in Halifax for at least a year, Mary Bradstreet Robie's letters contain little of Sewall's optimism. "So much for Halifax," she wrote in no unclear terms in January 1776. "I wish I had never seen it." ${ }^{33}$ Although it was on the cusp of major growth during the Revolution, when the Robies arrived in May 1775 Halifax remained a small outpost in the nascent British colony that bore little resemblance to the thriving town of Marblehead they had left behind ${ }^{34}$ Robie complained to her husband about being unable to find adequate care for a terrible toothache, half-jokingly writing "If you ever see me again I am afraid it will be without teeth." She decried the "dark and rainy Halifax weather," and prayed her husband would return from England and bring the family out of their captivity. Reminding her husband to send her best wishes to Sewall and his wife while they were together in London, Mary Bradstreet Robie quipped: "Make my best respects to the judge and Lady . . . and tell e'm [sic] I wish they will never see Halifax." ${ }^{35}$ From London, Robie attempted to reassure his wife by encouraging her to not live any differently in Halifax than she had in New England. "Tho I would by no means discourage frugality

31 Berkin, Jonathan Sewall, 115.

32 Jonathan Sewall to Thomas Robie, 15 July 1775, Robie-Sewall Family Papers, MHS.

33 Mary Bradstreet Robie to Thomas Robie, 9 January 1776, Robie-Sewall Family Papers, MHS.

34 The British established Halifax on the shores of the Chebucto Bay in 1749, a century after Marblehead had been incorporated into Massachusetts. While the port had grown since its inception it remained a small outpost compared to the bustling port of Marblehead, which was among the ten largest and wealthiest cities in the United States in 1790. On the founding of Halifax, see Jeffers Lennox, "An Empire on Paper: The Founding of Halifax and Conceptions of Imperial Space, 1744-1755," Canadian Historical Review 8, no. 3 (September 2007): 373-412.

35 Mary Bradstreet Robie to Thomas Robie, 9 January 1776, Robie-Sewall Family Papers, MHS. 
and economy," he advised her, "do not debar yourself the Necessities and Conveniences of Life on account of the unhappy situation of affairs. ${ }^{36}$

Most refugees who landed in Nova Scotia between Gage's evacuation of Boston in March 1776 and the final withdrawals from the last British strongholds of the eastern seaboard in late 1783 expressed feelings of unhappiness in ways similar to Mary Bradstreet Robie. Mary Driskill spoke of her "very Disconsolate position" when she arrived in Nova Scotia. Hannah Watson explained that her arrival left her with the "deepest Distress, Misery, and Indigence." ${ }^{7}$ Sarah Winslow believed the British government had abandoned its faithful subjects, who would spend their "last days in wretchedness." ${ }^{38}$ Although women appear more likely to express their discontent, Loyalist men also felt the despair. One refugee noted how even "strong proud men wept like babies." ${ }^{39}$ The gloom of exile was inescapable in Loyalist Nova Scotia.

The refugees were constantly aware of the sadness imbued within their society, and this feeling permeated even the more joyous occasions. Shortly before Christmas 1783, Mary Robie declined an invitation to attend a ball at the governor's mansion. In a letter years later, Robie explained to her sister that she detested the "stiffness and ceremony, which generally prevails in public places." ${ }^{30}$ While she did not attend, she used her experience at similar festivities to speculate in her diary about what the event would be like. "It gives me pleasure," Robie imagined, "in a large company to look around and see the appearance of happiness on every face and every eye sparkle with delight." But Robie recognized that beneath the joyful surface lay a more bleak reality. "I never dare to draw back the curtain to look what is behind all this apparent happiness," she explained, "les't I should find some times only gilded misery."

36 Thomas Robie to Mary Bradstreet Robie, 16 April 1776, Robie-Sewall Family Papers, MHS.

37 Quoted in Buszek, "'By fortune wounded'," 53.

38 W.O. Raymond, ed., The Winslow Papers, 1776-1826 (St. John, NB: 1901), 78.

39 Quoted in Buszek, "'By fortune wounded'," 56.

40 Mary Robie to Mehetable (Robie) Sterns, 28 January 1788, Robie-Sewall Family Papers, MHS. The ball before Christmas was only one of many celebrations in Loyalist Halifax. In the year that Robie kept her diary; she described two others balls - on the King's and the Queen's birthday. Although such gatherings were the highlight of the elite's social calendar, similar festivities held around the region suggest they were also attended by more middling people and a number of sailors and soldiers. In addition to religious services, these balls would have been one of the few times a variety of the Halifax population came together in one place. For a similar instance in Shelburne, see Huskins, "'Remarks and Rough Memorandums'," 110-11.

41 Mary Robie, diary, 11 December 1783, Robie-Sewall Family Papers, MHS. 
Robie, like so many other refugees, recognized the inescapable sadness that defined Loyalist society in Halifax even if it was not always apparent.

In an attempt to escape the signs of the widespread poverty of exile and to recreate the grandeur of their lives before the war, Loyalists held many large gatherings like the one Robie described. Robie found at least a modicum of comfort in the façade these gatherings provided. But she also knew that the merriment around her was superficial. She called the apparent happiness "only gilded misery" because she recognized the ball was merely a distraction that provided a thin veil to cover the harsh realities of exile..$^{42}$

But Robie's comment should not simply be dismissed as another example of Loyalist hardship. After all, she and the other ball attendees were members of the elite and therefore insulated against much of the physical suffering that less affluent refugees endured. Instead, Robie's thoughts suggest she recognized a common thread of emotion that connected all Loyalists. While she did not share the physical suffering, she wanted to imagine herself as part of the broader emotional community. ${ }^{43}$ As historian Joanne Burke argues, emotions, like suffering, have the power to "align individuals with communities." 4 Although only a brief note, Robie's emphasis on the pervasive sadness suggests that she understood the feeling of despair to be a critical component of the broader Loyalist experience. The "gilded misery" of exile provided a common bond between diverse refugees who shared little in common other than their sadness. ${ }^{45}$

This idea of "emotion shared" - or what 18 th-century people called "compassion," "sympathy," or "fellow feeling" - was a vital character trait. As Adam Smith noted in The Theory of Moral Sentiments (1759), "Nothing pleases us more than to observe in other men a fellow-feeling with all the emotions of our own breast; nor are we ever so much shocked as by the appearance of

42 For Loyalist gatherings, see Condon, "Family in Exile," in Conrad, Intimate Relations, 47.

43 On the importance of imagined connections to others, especially in relation to community formation, see Benedict Anderson, Imagined Communities: Reflections of the Origin and Spread of Nationalism (London: Verso, 1983).

44 Joanne Burke, "Fear and Anxiety: Writing About Emotion in Modern History," History Workshop Journal 55, no. 1 (Spring 2003): 124

45 Although letters between the Robies cease upon Thomas's return to Nova Scotia sometime in 1777, in Mary Bradstreet Robie's first letter back to Halifax from Massachusetts in 1784 she noted "I wish you was here, I am well assured you would never wish yourself in $\mathrm{H}$ [alifa]x again" and "I shall never be content to live as we have done there," suggesting her unhappiness with her adoptive home persisted through the 1780s; see Mary Bradstreet Robie to Thomas Robie, 8 August 1784, Robie-Sewall Family Papers, MHS. 
the contrary." British society emphasized the importance of fellow feeling and perceived those who did not demonstrate what one scholar has dubbed "irresistible compassion" as lacking a key component of humanity. Both men and women were expected to be conscious of the feelings of others. But unlike men, 18th-century women needed to protect themselves from being seen as overly sentimental, which Sarah Knott notes could cause them to be perceived as "the sign of sensibility gone wrong: ineffectual, excessive, and affected." ${ }^{36}$ Women in Loyalist Halifax, therefore, had to toe a fine line between compassion and composure. Ultimately, Loyalist women like the Robies found they could demonstrate both these qualities in an important public role: the compassionate neighbor. Through this position, women established important personal connections and set the precedent for a new emotional community in exile.

One duty Loyalist women assumed as compassionate neighbors was to visit newly arrived refugees, even if they were strangers. As refugees flocked to Halifax during late 1783 , women's visits to homes of strangers became increasingly common. This custom became so routine that, in writing back to his aunts in Massachusetts, Mather Byles III noted his sister Rebecca, in contrast to her peers, "never goes to see a stranger that arrives because she supposes they are like all the rest." 47 Although this comment highlights some of the class divisions in Loyalist Halifax, Byles's note also emphasizes how other elite women (such as the Robies) made it a habit to visit newly arrived refugees regardless of social status. His remark also demonstrates how women's visiting practices, especially to homes of "strangers," were highly visible and important public functions.

In early October 1783, Mary Robie described the busy day her mother had visiting newly arrived Loyalist families throughout Halifax. She noted that although these families were "strangers," they were also "people of character" and "Mama visited them from a motive of compassion as they knew nobody

46 On the importance of sympathy and compassion in the 18th century, see Adam Smith, The Theory of Moral Sentiments, ed. Knud Haakonssen (Cambridge: Cambridge University Press, 2002), quotation on 17 and Norman S. Fiering, "Irresistible Compassion: An Aspect of Eighteenth-Century Sympathy and Humanitarianism," Journal of the History of Ideas 37, no. 2 (April-June, 1976): 195-218. On women and the dangers of being overly sentimental, see Rosenwein, Emotional Communities, 86; Knott, Sensibility and the American Revolution, 230; and Claudia Johnson, Equivocal Beings: Politics, Gender, and Sentimentality in the 1790s: Wollstonecraft, Radcliffe, Burney, Austen (Chicago: University of Chicago Press, 1995).

47 Quoted in Neil MacKinnon, This Unfriendly Soil: The Loyalist Experience in Nova Scotia 1783-1791 (Montreal and Kingston: McGill-Queen's University Press, 1986), 86. 
here." 48 Although Robie's emphasis on these refugees' "character" might suggest these refugees were fellow elites, evidence from colonial newspapers demonstrates that by the $1780 \mathrm{~s}$, British sympathizers used this term to mean colonists who had remained loyal. For example, in a 1780 address to the departing military commandant, New York's mayor, David Matthews, reminded Major General James Pattison to remember the colonists of New York to British officials in London by "our characters, as loyal and affectionate subjects to the best of kings." ${ }^{39}$ In a letter to the Earl of Shelburne reprinted in the South-Carolina Weekly Gazette, a sympathetic Briton praised the "brave and loyal men in America," who through their sacrifices demonstrated the "character particular to Britons." ${ }^{\circ}$ Given that Robie noted the arrivals had no connections in Halifax, it is likely that her emphasis on the refugees' character referred to their status as colonial Loyalists rather than an elite class standing.

Visiting newly arrived strangers was a marked change from the Robies' normal social calls. Prior to the influx of refugees in 1783 , the family mostly kept company with fellow New England refugees, many of who were close friends, and who had also come from Marblehead and the surrounding area during the late $1770 .^{51}$ But the "strangers" they visited in October 1783 were refugees from New York, which had been evacuated over the summer months..$^{52}$ Visiting newly arrived refugees, Mary Bradstreet Robie practiced "extradomestic sociability" and blurred the lines between private and public practice. During these visits, she both judged the character of the new arrivals and increased her own intimate circle while also providing a larger public service of acclimating new arrivals to Loyalist Halifax..$^{53}$ Through her visiting practices,

48 Mary Robie, diary, 4 October 1783, Robie-Sewall Family Papers, MHS.

49 New-York Gazette and Weekly Mercury (New York), 4 September 1780.

50 South-Carolina Weekly Gazette (Charleston), 12 April 1783.

51 Mary Robie's diary and her father's letters reveal the most common visitors to the Robie household were other New England refugees like Benjamin Marston, Ward Chipman, Rev. Mather Byles Jr., the Shaw family, and Jonathan Sterns among others. Choosing to keep company with refugees from the same region was not unusual or characteristic of only the Nova Scotian Loyalists. Mary Beth Norton explains how New England refugees in London "virtually adopted [St. James Park] as their own private preserve"; see Norton, The British-Americans: The Loyalist Exiles in England 1774-1789 (Boston: Little, Brown and Company, 1972), 66-7.

52 On the British evacuation of New York and the ways in which the New York Loyalists differed from earlier exiles, see Ruma Chopra, Unnatural Rebellion: Loyalists in New York City During the Revolution (Charlottesville, VA: University of Virginia Press, 2011), chap. 6 and 7.

53 For perhaps the most comprehensive account of late-18th-century women and how their private and public roles often mixed, see Laurel Thatcher Ulrich, A Midwife's Tale: The Life of Martha Ballard Based on Her Diary, 1785-1812 (New York: Alfred A. Knopf, 1990). 
Robie was not simply imagining a more exciting lifestyle or attempting to relive the glory of her pre-revolutionary station; instead, her visits provided a valuable first point of contact for new arrivals, provided the Robie family with an extended network, and served as an important symbol of public empathy to the broader Loyalist population of Halifax..$^{54}$

Mary Bradstreet Robie used her visits to build "an environment of mutual benevolence, fictive kinship, and friendship" between the earlier refugees and those of 1783.55 For the newly landed refugees, Robie's visits provided an important link to their new home. As a well-connected earlier arrival, Robie would have been a valuable source for information. In her parlour on Granville Street she hosted some of the most prominent figures in the colony, including Lt. Governor Edmund Fanning, the surveyor of the Port Roseway (Shelburne) settlement Benjamin Marston, the chaplain to the army at Halifax Mather Byles Jr., the minister of St. Paul's Anglican Church Dr. John Breynton, and Rev. Peter De la Roche of Lunenburg and Rev. John Wiswall of Cornwallis. When she visited new families, she could have provided them with some of the insights she gained from conversing with these elite figures in her own home. Certainly Robie benefited from these new settlers as well. Through her visits she was able to both learn about life in the other Loyalist strongholds and assess the new arrivals' potential benefit to her own inner circle.

But these visits also served an important emotional function. Having lived through the hardships of settling in Halifax herself, Robie represented an empathetic figure to new arrivals. She helped the refugees make sense of their new home and provided essential functions of support for these new strangers. Perhaps most demonstrative of her public position of support, Robie volunteered her daughters to mourn alongside families coping with the loss of a loved one. While visiting new families, Robie learned of a young woman who, having been separated from her parents during the war, died shortly after arriving in Halifax. Survived only by her siblings, whom she had cared for, the woman had no one else to mourn her death. Although many 18 th-century

On the importance of "extra-domestic" activities, see Claude Grignon, "Commensality and Social Morphology: An Essay of Typology," in Food, Drink, and Identity in Europe Since the Middle Ages, ed. Peter Scholliers (Oxford: Berg Publishers, 2001), 27 and Huskins, "'Remarks and Rough Memorandums'," 105-6. On the propensity of historians to impose artificial divides between women's communal and domestic functions, see Terri $\mathrm{L}$. Snyder, "Refiguring Women in Early American History," William and Mary Quarterly 69, no. 3 (July 2017): 423-4. 
colonists eschewed grandeur and spectacle in funerals, popular custom still dictated that respected and loved individuals command large turnouts for their burials as a sign of respect. ${ }^{6}$ Funerals in Halifax, and throughout the Loyalist settlements of Nova Scotia, however, were often sparsely attended, which contributed to the feeling of a "lonely death" in exile.57

The connection forged by Mary Bradstreet Robie during her visit meant that the newly arrived family now had potential mourners to attend the young woman's funeral, and on the evening of 3 October 1783, Mary Robie and her sister received a request "to serve as pallholders to a Miss Wood." "We had never any connection, or even knew there was such a person here," Robie explained, but after learning of the family's plight the Robie sisters consented to visit the family. Being asked to serve at the funerals of young men and women they had never met was not entirely uncommon for young Loyalist women of Halifax. Both Mather Byles Jr. and his 20-year-old daughter Rebecca attended the funeral of another recent arrival on 4 February 1784. Rebecca, who was serving as "bearer for a girl of her acquaintance" was given special clothing - "white gloves and white ribbands [sic]" - which he noted was "the usual custom of such funerals in this place." ${ }^{38}$ Mary Robie also noted the particular mourning rituals of Halifax while attending another funeral: “The pall was held by six young Women dressed in white with Hoods that covered their faces and the corps $[s i c]$ was lowered only by males," Robie explained. "Everything was conducted with decency as [the deceased] had left directions." ${ }_{59}$ The description of Loyalists' grieving practices, especially the unique clothing

56 Clare Gettings, Death, Burial, and the Individual in Early Modern England (London: Croom Helm, 1984), 110-18; Gloria L. Main, Peoples of a Spacious Land: Families and Cultures in Colonial New England (Cambridge, MA: Harvard University Press, 2001), 185; Poulter, "What's Traditional about 'the traditional funeral'?" 133-59.

57 The study of forced exiles and captives demonstrates that refugees often consider their removal from home a sort of living death. From the poet Ovid's exile to the experience of "social death" for slaves forced across the Atlantic, exiles and captives often saw their exile as similar to death. See Vincent Brown, "Social Death and Political Life in the Study of Slavery," American Historical Review 114, no. 5 (December 2009): 1231-49; Sabine Grebe, "Why Did Ovid Associate His Exile with a Living Death?" Classical World 103, no. 4 (Summer 2010): 491-509; and Orlando Patterson, Slavery and Social Death: A Comparative Study (Cambridge, MA: Harvard University Press, 2005). But biological death in exile, where one was cut off from kin and homeland, represented a special finality. For a modern autobiographical account of exile and its relation to both biological and social death, see Marta Raquel Zabaleta, "Exile," Feminist Review 73 (2003): 19-38. On the idea of a "lonely death" in exile, see Edward Said, Reflections on Exile and Other Essays (Cambridge, MA: Harvard University Press, 2000), 555.

58 Mather Byles Jr., diary, 4 March 1784, in Mather Byles Jr. to Polly and Kitty Byles, 10 June 1783, Byles Family Papers, NSA. 
mourners wore, suggests the refugees developed their own customs for mourning in exile. Funerals in Loyalist Halifax were marked by more than distinctive dress, as the participation of unknown strangers from the Loyalist community demonstrated the power of collective loss and shared suffering to create community.

Mary Robie's empathic thoughts while visiting the grieving family and at the graveside of the stranger demonstrate the importance of "gilded misery" to the community of Loyalists in Halifax. "As strangers we pitied them," she explained after meeting the deceased's surviving siblings, "and [we] looked upon ourselves obliged to be of all the service in our power." her thoughts on the burial, Mary further commented, "This was a young woman of six and twenty, who after a short illness was cropped, as it were, in the flower of her age in a strange place unknown and unlamented." ${ }^{11}$ While she had never met the departed, as a fellow refugee in Nova Scotia Robie intimately understood the young woman's struggles and worried she too would share a similar lonely death in exile. Robie's tears at the stranger's graveside were a sign of her compassion and served to reinforce Loyalist community. ${ }^{62}$ Robie's presence and compassion at the young woman's funeral demonstrate the importance of fellow feeling to the Loyalist community of Halifax and reveal the highly visible role of women within this emotional community.

\section{The Robie women and repatriation}

During the spring of 1784 , Halifax saw the arrival of thousands of Loyalist exiles, and the Robies welcomed a new baby to their own household. Mary Bradstreet Robie gave birth to her final child, a daughter named Hannah, on 12 March $1784 .{ }^{63}$ While the family celebrated the child's birth as a blessing, her mother closely watched the deteriorating conditions around Halifax with apprehension. An ominous and unsettling mood seemed to settle over the city during the early months of 1784 , and Hannah's birth reinvigorated her mother's desire to return to Massachusetts. Although her husband remained committed

60 Mary Robie, diary, 3 October 1783, Robie-Sewall Family Papers, MHS.

61 Mary Robie, diary, 4 October 1783, Robie-Sewall Family Papers, MHS.

62 On the tears as performance of refined civility, see Nicole Eustace, Passion is the Gale: Emotion, Power, and the Coming of the American Revolution (Chapel Hill, NC: University of North Carolina Press, 2008), 161-2 and Anne Vincent-Buffault, trans. Teresa Bridgeman, The History of Tears: Sensibility and Sentimentality in France (London: St. Martin's Press, 1991), 9. On tears as a symbol of belonging, see Grant, "Enthusiasm and Loyalty," 311-13. 
to staying in Nova Scotia, Mary Bradstreet Robie became insistent that a return to their American home was in the family's best interest. ${ }^{64}$ The role Robie played in bringing her family out of exile demonstrates that not all Loyalist women accepted their fate as permanent exiles. ${ }^{65}$ More importantly, Robie was able use the omnipresent gloom of Loyalist exile to sway her husband's opinion on repatriation.

Many Loyalists were unhappy with the disadvantageous terms reached between Great Britain and the United States at the Revolution's end, especially the ambiguous language about the restoration of Loyalist property ${ }^{66}$ The final British defeat, and what was essentially the capitulation of Loyalist property, only cemented despair in collective consciousness of Loyalist Halifax. Such sadness manifested itself in a number of ways. The younger Mary, for instance, began her diary entry for 29 February in the following way: "Thank heaven this [day] is past ... for we have had two dreadful predictions, one public the other private." Since the British colonies adopted the Gregorian calendar in 1752, leap years were known to excite superstitions among many colonists. ${ }^{67}$ For the Loyalists of Halifax, the leap year of 1784 coincided with the disastrous end of the war and the haphazard resettlement of refugees. Within this calamitous atmosphere, a dire rumour gained considerable traction. "It was predicted that the day was to be as dark as night," Robie explained, "[and] that there was a most violent storm, and that the greatest part of the city was to be overflowed by inundation." Her younger brother Thomas also confided in his sisters that he had "dreamt he was going to die on the twenty ninth of February," which his sister described as "extraordinary" because "it was a leap year and he knew it not." Robie felt considerable distress as she "had heard several stories of people who had foretold the time of their own death," but, she explained, she had decided to "keep it carefully from my mother" who was expecting the birth of

64 Although there had been an increase in anti-Tory rhetoric in Massachusetts during the year 1783, by 1784 even the most ardent patriots recognized the reintegration of some Loyalists could be beneficial for the postwar economy. See Kermes, "Return of the Massachusetts Loyalists"; David Edward Maas, "Massachusetts Loyalists 1775-1790," in Loyalists and Community in North America, ed. Robert M. Calhoon, Timothy M. Barnes, and George A. Rawlyk (Westport, CT: Greenwood Press, 1994); and Brannon, From Revolution to Reunion.

65 Condon, "Family in Exile," in Conrad, Intimate Relations, 47.

66 Joseph Galloway, The Claim of the American Loyalists Reviewed and Maintained Upon Incontrovertible Principles of Law and Justice (London: T. Wilkie, 1783).

67 Robert Poole, "'Cive Us Our Eleven Days!': Calendar Reform in Eighteenth-Century England," Past \& Present 149, no. 1 (November 1995): 125. 
her child any day. ${ }^{68}$ More than children's gossip, the worrying rumours Robie recorded in her diary speak to the ever-present gloom that shrouded Loyalist Nova Scotia when Hannah Robie was born. ${ }^{69}$

Intensifying feelings of unease around the period of Hannah's birth, the delivery had been difficult for the aging mother. Although the baby was born healthy, the long and laborious birth left the family feeling "poignant uncertainty." ${ }^{\circ 0}$ Mary Bradstreet Robie's recovery from Hannah's birth was slow, but this was not necessarily unusual for upper class women of the period..$^{71} \mathrm{By}$ early May Mary Bradstreet Robie was dining with family, and her daughter noted that her health and spirits were both "remarkably well." 72 By the month's end, however, the health of both mother and child took a serious turn for the worse. In Mary Bradstreet Robie's eyes, their ill health was symptomatic of widespread diseases, especially smallpox, that had come to Halifax with the influx of refugees. ${ }^{73}$

Lacking proper medical attention and fearing the worst for both her own health and that of her newborn, Mary Bradstreet Robie became increasingly vocal about her desire to exchange disease-ridden Halifax for Massachusetts. Perhaps fearing his former neighbours would take revenge on his wife and children, or maybe worried the sickly woman and child would not survive the notoriously rough crossing between Nova Scotia and New England, Thomas Robie resisted his wife's pleas for return. ${ }^{74}$ Instead of the oversea journey, he arranged to bring the family out of Halifax and into the country. On 25 June 1784 the family took a carriage from Halifax to the home of one of Robie's business associates in Sackville, roughly 12 miles north. For the younger Mary, the family's journey into the country was an adventure. Unhappy that she had

68 Mary Robie, diary, 29 February 1784, Robie-Sewall Family Papers, MHS.

69 On the power of rumour to affect colonial peoples of the Atlantic world, see Wim Klooster, "Slave Revolts, Royal Justice, and a Ubiquitous Rumor in the Age of Revolutions," William and Mary Quarterly 71, no. 3 (July 2014): 401-24 and Antoinette Sutto, Loyal Protestants and Dangerous Papists: Maryland and the Politics of Religion in the English Atlantic, 1630-1690 (Charlottesville, VA: University of Virginia Press, 2015), chap. 9.

70 Mary Robie, diary, 12 March 1784, Robie-Sewall Family Papers, MHS.

71 On lying-in periods, see Ulrich, Midwife's Tale, chap. 5 (esp. 171-3).

72 Mary Robie, diary, 8 May 1784, Robie-Sewall Family Papers, MHS.

73 On instances of disease that spread through Halifax and other Loyalist settlements following the arrival of the refugees in 1783, see Allan Everett Marble, Surgeons, Smallpox, and the Poor: A History of Medicine and Social Conditions in Nova Scotia, 1749-1799 (Montreal and Kingston: McGill-Queen's University Press, 1993), chap. 4.

74 On the rough crossings between Nova Scotia and New England, see Ross, "Adaptation in Exile," 87-90. 
only "been 4 miles out of town" since she arrived 9 years earlier, she welcomed the opportunity of seeing other regions of Nova Scotia. ${ }^{75}$ The excursion was little help, and Robie's diary indicates her mother's health continued to decline rapidly upon their return to Halifax in early July. After the failure of his country excursion, Thomas yielded to his wife's wishes and prepared arrangements for her passage back to New England.

In early July 1784, Mary Bradstreet Robie, her eldest daughter Mary, and the newborn Hannah boarded a ship destined for New England. This was the family's first excursion home since their exile almost a decade before. The 10-to-12 day sail between Halifax and Massachusetts was a treacherous and tiresome voyage for seasoned seamen, but for a sick mother, her 3-monthold child, and a 20-year-old tasked with watching over the ailing family the crossing was excruciating. Upon arriving in Massachusetts, the younger Mary explained how all aboard the New England bound ship had "tremble[d] at the idea of the long passage" with the wind against them. The journey was arduous, and although the younger Mary had escaped the "sea sickness" that plagued nearly all aboard, her mother and young sister had suffered tremendously. They fared little better after landing in Massachusetts, where they stayed in Salem with her father's sister, Mehitable Higginson, who had herself returned from Halifax sometime in early $1783 .{ }^{76}$ Mary spent days tending to them. "The first moment of leisure I had after being a little recovered from the fatigue of the voyage in my heart I dedicated to writing you," Mary explained in a letter to her sister in Halifax, "but Mama and the baby having both been rather indisposed necessarily engaged all of my attention." 77

Back in Halifax, Thomas Robie wrote his wife a few letters suggesting he was still not entirely comfortable with her return to New England. "I must repeat my desire," he wrote to his wife in late July, "that you find a [wet] Nurse

75 Mary Robie, diary, 24 May 1784, Robie-Sewall Family Papers, MHS.

76 The only evidence that survives of Higginson's return to New England comes from a letter her cousin, Jonathan Sewall, sent to Massachusetts from London, where he relayed surprise upon having learned Higginson had returned home. "When I saw your letter dated Salem," Sewall began, "I was as much astonished as if it had been dated at Calcutta or on the moon." Although humorous, Sewall's astonishment suggests very few Loyalists had returned to New England from Nova Scotia by September 1783. As a widow, Higginson might have been able to return more freely than men and married women. She operated a school there with her daughter well into old age. See Jonathan Sewall to Mehitable Higginson, 10 September 1783, Robie-Sewall Family Papers, MHS. On Higginson's career in Salem, see John J. Lattivo, "Salem Loyalists - Mrs. Mehitable Higginson," New England Historical \& Genealogical Register and Antiquarian Jourmal 26, no. 4 (1872): 431-2. 
for Miss Hannah . . . as you are now in a Land flowing with Milk if not with Honey." ${ }^{8}$ While he wished his wife a speedy recovery, he reiterated that her travel was a temporary fix. Despite his fears, Robie was certain that once his wife returned to New England she would recognize how much better life in Halifax was than Massachusetts and would "come back in good spirits." 79

By 8 August, Mary Bradstreet Robie was well enough to write her husband a short letter, but her words did little to reassure her worrying spouse. Contrary to what her husband believed, Robie wrote that she found life in New England was far superior to her experience in Halifax. "I wish you was here," she wrote, and assured him that if he returned to Massachusetts "you would never wish yourself in H[alifa]x again." Being back in New England confirmed what Mary Bradstreet Robie had imagined all along, and having tasted happiness again for the first time in years she had no desire to return north. "In short you must come here or I shall elope again," she threatened her husband, "for I shall never be content to live in the way I have done there." ${ }^{\circ 0}$ Robie's threat was not entirely clear; she implied, however, that if her husband would not consider returning to New England she would continue to make trips back herself. She may have even been alluding to the idea that she would leave him for a permanent return. Although Robie and her daughters had played an important public role in Loyalist Halifax, she yearned for a return to a more stable lifestyle in Massachusetts.

Her daughter, however, was less keen on the idea of repatriation. The younger Mary felt a sense of relief and joy similar to her mother's when she landed back in New England. "I cannot pretend to tell you how we felt when we first saw land, or of my emotion of coming ashore," she wrote to her sister Hetty in Halifax, "I am certain your heart will give you a much better idea than my pen." But while she rejoiced in her family's return, her outlook on the future was starkly different from her mother's. She had built a group of good friends in Halifax and still felt a strong connection to the Loyalist community in exile. Contemplating the contrast between the happiness she felt on arriving in New England and the sadness that remained from leaving friends in Halifax, Robie wrote: "I could be contented here as formerly; however, I by no means wish

78 Thomas Robie to Mary Bradstreet Robie, 13 July 1784, Robie-Sewall Family Papers, MHS (emphasis his own). Thomas's comment concerning the land "flowing with Milk if not with Honey" was likely a jab at the disorder of the early United States.

79 Thomas Robie to Mary Bradstreet Robie, 26 July 1784, Robie-Sewall Family Papers, MHS.

80 Mary Bradstreet Robie to Thomas Robie, 8 August 1784, Robie-Sewall Family Papers, MHS 
it. My Halifax friends still have too much hold on my heart." ${ }^{\text {81 }}$ The younger Robie's connections to Nova Scotia were much stronger than her mother's.

Perhaps recognizing that she stood alone in her desire to return, Mary Bradstreet Robie knew that, despite her threats, she had no leverage. In the same letter where she expressed her desire to repatriate, she also assured her husband of her fidelity. "You know I shall (not withstanding what I have said above) prefer being with you, wherever you think it will be best." ${ }^{22}$ Family remained paramount in her mind, and while a return to New England confirmed what she had believed she also recognized she would not be fully content in Massachusetts without those she loved. As she wrote to Thomas: "My love to the children. I hope you are attentive ... tho [I am not] superstitious [I am] anxious, and should anything happen, I should be more unhappy than if I had not left home." ${ }^{3}$ Three of her children and her husband remained in Halifax, and she knew she belonged with them. She and her daughters set sail back to Nova Scotia in late October 1784 .

Unfortunately for Mary Bradstreet Robie's ambitions, the family's connections to Nova Scotia only grew stronger after she returned to Halifax. Sometime in late 1784 or early 1785 , Hetty Robie agreed to marry Jonathan Sterns. Sterns, a close family friend and fellow New England refugee, was 15 years Hetty's elder but had been a frequent visitor to the Robie household, and Hetty's father looked favorably on the marriage between his daughter and an established lawyer and political representative of the Loyalist faction in Halifax. The couple gave birth to their first child sometime in 1786. After the marriage, Simon Bradstreet, the eldest Robie boy, began studying law with his new brother-in-law. ${ }^{84}$

81 Mary Robie to Mehetable Robie, 20 July 1784, Robie-Sewall Family Papers, MHS.

82 Mary Bradstreet Robie to Thomas Robie, 8 August 1784, Robie-Sewall Family Papers, MHS.

83 Mary Bradstreet Robie to Thomas Robie, 8 August 1784, Robie-Sewall Family Papers, MHS.

84 While the arrival of thousands of refugees offered some advantages to the prerevolutionary settlers of Nova Scotia, especially in terms of increasing the British population in the colony, many worried the Loyalists would seize control of the legislature during the elections for sixth General Assembly, which opened on 8 November 1785. Only 13 of 49 elected members were Loyalists; but many campaigns had been hotly contested, which helped solidify political divides between the refugees and pre-revolutionary Nova Scotians. These divisions became even more prominent during a special by-election held in Halifax to fill the seat left vacant by S.S. Blowers. Representing Loyalist interests, Jonathan Sterns railed against corruption in the government and attacked his opponent, Samuel Morris, as a "sycophant." Violent altercations broke out between supporters on both sides. In the end, Sterns's status as a Loyalist made him an outsider and Morris won the election. Tensions between the two factions, however, 
At the same time, Thomas Robie purchased property through his connection with fellow Marblehead Loyalist Benjamin Marston in the growing settlement of St. John. Marston encouraged Robie to bring his hardware business to New Brunswick, explaining that not only did Robie's land sit on the "only Passage through which all the waters of that mighty [St. John] River flow into the Ocean" but also that the new settlement had both "Good Soil \& Good Government" that "certainly exceed you in Nova Scotia beyond all degrees of comparison." Furthermore, Marston assured Robie "the best People among you are all looking toward this New Province." ${ }_{55}$ With favorable prospects, Robie considered moving with other discontented Nova Scotian Loyalists to New Brunswick. ${ }^{86}$

With their ties to the region increasing, Mary Bradstreet Robie recognized she needed to develop a new strategy to convince her husband to bring the family, at least those not bound to Nova Scotia, back to New England. Knowing her husband's business had slowed since the conclusion of the war, she hoped to entice him with economic arguments. ${ }^{87}$ During her first trip to New England, Robie had recorded that the Massachusetts market was growing. "The town is upon the rise," she explained in 1784, "[and] all the men say on the wharf, 'Oh if we had but Mr. Robie's shop to go to'" "88 She reiterated these sentiments in 1787 , and her husband, looking to expand his business by at least testing the markets in New England, agreed to let his wife return to sell some products he was having trouble moving in Halifax. Mary Bradstreet Robie, her daughters

remained well into the 1790s; see MacKinnon, This Unfriendly Soil, 109, 121-6. On Sterns, see Barry Cahill, Philip Girard, and Jim Philips, eds., The Supreme Court of Nova Scotia, 1754-2004: From Imperial Bastion to Provincial Oracle (Toronto: University of Toronto Press, 2004), 66-70, 99. For the birth of the Robies' first grandchild, see Thomas Robie to Ward Chipman, 7 December 1786, Robie-Sewall Family Papers, MHS.

85 Benjamin Marston to Mary Robie, 15 May 1785, Robie-Sewall Family Papers, MHS (emphasis his own).

86 On the establishment of New Brunswick and its connection to dissatisfied Nova Scotians, see Anne Gorman Condon, The Envy of the American States: The Loyalist Dream for New Brunswick (Fredericton: New Ireland Press, 1984).

87 A letter from Thomas to a partner suggests that his sales continued a steady downturn after because of a lack of investment from the British military. While Robie "still hope[d] [for] better times for trade... [when] articles of export will gradually supply the place of that flood of money, which the Peace has put a stop to," he was also concerned that profits would never return to the wartime levels; see Thomas Robie to Ward Chipman, 7 December 1786, Robie-Sewall Family, MHS. 
Mary and Hannah, and a young black servant boy named Prince, sailed for Marblehead in October $1787^{89}$

Mary Bradstreet Robie quickly established herself as a hardware vendor out of the same home her family rented in Marblehead. By early November, she was writing back to Halifax about business. Although they sold "not a farthing" the whole first week, by the second week she was making around five dollars a day. ${ }^{\circ}$ While business was not as profitable as she hoped, she continually emphasized the positives of the return and encouraged her daughter to do the same. "Every body in this Town would be glad to have you return," the younger Mary obligingly told her father, "former animosities were all forgot." "Mr. Martin says you would do much better here than where you are," Mary Bradstreet Robie wrote in reference to one competitor, "and so many others, they all say ... your things are better than what they get of others and you was honest." ${ }^{\prime 2}$ Robie's letters to her husband were repeatedly positive, even if business was not what she had hoped.

Although she could paint a rosy picture of sales, the younger Mary was also less inclined to deceive her father and included in her letters more sobering news. While her mother had requested that her husband send more items from Halifax, Mary believed it "more advisable" for him to try and sell most hardware items in Halifax as "everything of that kind is much lower here [in Marblehead] than at Halifax." Mary also contradicted her mother's description of their competitors. She described the business of Mr. Hale and Mr. Scooby, which "undersells every body." Making matters worse, she believed, "every thing here sells under the sterling cost," and she warned her father "I find

89 I use the word "servant" to preserve the family's own explanation of the boy's status. It is abundantly clear that the Robies owned slaves in Halifax, but the young boy's exact legal status in New England is unclear. The Robies most likely brought a young boy back to Massachusetts because the state had outlawed slavery in 1783, and the boy's age kept him dependent on the family even if he could not be legally enslaved. On the Robie's ownership of slaves in Nova Scotia, see Mary Robie, diary, 5-6 June 1783, Robie-Sewall Family Papers, MHS. On abolition in Massachusetts, see Chernoh M. Sesay Jr., "The Revolutionary Black Roots of Slavery's Abolition in Massachusetts," New England Quarterly 87, no. 1 (March 2014): 99-131 and Joanne Pope Melish, Disowning Slavery: Gradual Emancipation and "Race" in New England, 1780-1860 (Ithaca, NY:

Cornell University Press, 1998), 64-83. On the status of "servants" in revolutionary Nova Scotia, see Harvey Amani Whitfield, North to Bondage: Loyalist Slavery in the Maritimes (Vancouver: UBC Press, 2016).

90 Mary Bradstreet Robie to Thomas Robie, 12 November 1787, Robie-Sewall Family Papers, MHS.

91 Mary Robie to Thomas Robie, 29 October 1787, Robie-Sewall Family Papers, MHS.

92 Mary Bradstreet Robie to Thomas Robie, 1-5 November 1787, Robie-Sewall Family Papers, MHS. 
nothing that will bear so great a profit here as at Halifax." ${ }^{93}$ While Mary Bradstreet Robie was careful only to relay all the well wishes and positive news, her daughter more accurately described the low cost of goods and competitive market in New England. 94

Despite her pessimistic outlook, the younger Mary continued in the trade and began a close study of the market. Throughout the early months of 1788 she continued to correspond with her father about the price of goods and requested he send specific items she believed would easily sell in Marblehead. Soon, her store was selling a good deal of hardware items imported from Halifax. Noting the tendency of other vendors, especially that of her close friend Joseph Sewall, to sell items "so cheap [that] others are forced to sell cheaper or not sell at all," she only requested hardware she knew could not be found in other stores. ${ }^{95}$ Having sold all of the small and large pins Thomas sent from Halifax, she requested he send more, along with "White Chapel Needles" that she believed "would sell quite well here." She also advised her father to secure "knives and forks," "Horn combs," and "Knitting Kneedles."96 She monitored other vendors closely, learning what prices she could charge to entice customers away from the competition while still charging prices close to those her father requested.

Even with her growing expertise in the hardware business, the younger Mary longed for Halifax. By the early spring months of 1788 she had been away from Nova Scotia longer than she had ever been before, and her letters north began to reflect her desire to return. "I hope that you continue to take your evening Walk whenever the weather will admit of it," Mary wrote to her father. She asked him to remember her to the many families he would visit while out walking. She concluded that she wished to be back with her friends and family soon. ${ }^{97}$ And in a letter addressed to her sister Hetty, she explained "Absent from my Friends so dear, the most delightful scenes lose half their charms." ${ }^{98}$ As the months pressed on, the younger Mary looked back to Halifax for her happiness.

93 Mary Robie to Thomas Robie, 17 November 1787, Robie-Sewall Family Papers, MHS.

94 Mary Bradstreet Robie to Thomas Robie, 24 November 1787, Robie-Sewall Family Papers, MHS.

95 Mary Bradstreet Robie to Thomas Robie, 3 February 1788, Robie-Sewall Family Papers, MHS. Joseph Sewall was a distant relation of Mary's grandmother Mehetable (Sewall) Robie. After the family's arrival in 1787, Sewall assisted Mary Bradstreet Robie and Mary Robie in a number of ways. Most importantly, he helped Thomas settle a number of debts he owed to the town.

96 Mary Robie to Thomas Robie, 25 March 1788, Robie-Sewall Family Papers, MHS.

97 Mary Robie to Thomas Robie, 25 March 1788, Robie-Sewall Family Papers, MHS.

98 Mary Robie to Mehetable (Robie) Sterns, 5 May 1788, Robie-Sewall Family Papers, MHS. 
Aware of her daughter's growing desire to return to Nova Scotia, Mary Bradstreet Robie became increasingly anxious about their time in New England. Robie had become less involved in the business as her daughter's interest in the market increased, and if the younger Mary wrote north that it would best to close shop and return to Halifax there would be little her mother would be able to do to stop it. She could, however, find a suitor for her unmarried daughter. The younger Mary had developed a friendly contest with local competitor Joseph Sewall. Robie often joked to her father that Sewall's expertise as a merchant threatened to drive her business under. Sewall probably felt similarly. He had arrived in Marblehead from Boston in November 1785 with "a small assortment of goods" which did not exceed $£ 300$. By 1788, Sewall estimated his annual profits to be a modest “ $£ 800$ to $£ 900$ ” and his total property to be another $£ 900$. Although he only turned a small profit each year, Sewall recognized that combining his venture with Robie's would help corner the market in the region and give him access to better quality goods coming in from Halifax. He no doubt cared for Mary, but also recognized their merger would benefit both families' business operations. Sewall proposed marriage to Mary Robie in early July $1788 . .^{99}$

Mary Bradstreet Robie appears to have played a significant role in encouraging Sewall to propose. Although Sewall had wanted to ask Robie to be his wife, he was aware his intended's continued connection to friends and family in Halifax made a New England marriage undesirable. When Sewall wrote to Thomas Robie in Nova Scotia, he explained his hesitations, but also noted that Robie's wife had encouraged him to ask for her daughter's hand. "I should not have presum'd Sir, to make this application," he wrote, "if I had not had some degree of encouragement from Mrs. Robie, for whom I shall ever entertain the most grateful regard." ${ }^{100}$ Mary Bradstreet Robie also wrote to Halifax explaining she had already given her consent and she warned her husband "You will not object." While she recognized "it will be a hard blow to me and all her friends at H[alifax] to part with her," she also stressed "we should all give up self when she is to be the gainer." She implored her husband to remember the "endearments of a tender father" and consent to his daughter's lasting happiness. ${ }^{101}$ While the New England business had been less than successful, it had produced a marriage. Mary Bradstreet Robie again

99 Joseph Sewall to Thomas Robie, 29 July 1788, Robie-Sewall Family Papers, MHS. 100 Joseph Sewall to Thomas Robie, 29 July 1788, Robie-Sewall Family Papers, MHS. 101 Mary Bradstreet Robie to Thomas Robie, 29 July 1788, Robie-Sewall Family Papers, MHS. 
emphasized the good of the family and played to her husband's role as father in order to cement a connection back to New England.

Thomas Robie seemed to understand that his distance from Massachusetts necessitated that his wife and daughter act without his express consent. He also agreed the marriage was in his daughter's best interest. But as a dutiful father, he was sure to write his daughter with "one or two hints" regarding "that new relation you now sustain." Perhaps reflecting some of the quarrels he had with his own wife, Robie instructed his daughter to "never affect to have your own way or persist with your husband by any other method than a decent and mild endeavor to persuade him ... by all means give way rather than appear to contest." ${ }^{102}$ While not out of line with 18th-century marriage ideals, Robie's comments to his daughter were born out of some of his own frustrations with his own marriage. Perhaps he also recognized his wife had finally gained the upper hand through the new union.

Mary Bradstreet Robie arrived back in Halifax in November 1788 with a tangible connection back to New England through her daughter's marriage and an "exceedingly anxious" desire to hear all the news coming from Massachusetts. ${ }^{103}$ Her stay in Halifax was short. She left Halifax for Marblehead again in early May of the following year to help her daughter with her first pregnancy. This time she brought her youngest son, Thomas Jr., with her to help care for the growing Hannah and, although it is unclear what arrangements she had worked out with her husband, with most of her family back in New England she appears to have had little intention of returning to Nova Scotia. Her husband was also beginning to see his new connection with Sewall provided more stability than his business in Halifax or possible opportunities in St. John. ${ }^{104}$

Mary Bradstreet Robie's voyage in 1789 marked her last trip between Massachusetts and Nova Scotia. The same day she arrived in Marblehead she wrote back to Thomas: "If you ever expect to see me again, you must come here. It will be greatly for your interest to come and the sooner the better."105 With his daughter married in Massachusetts, his business opportunities expanding in New England, and his wife and youngest son removed to Marblehead as well,

102 Thomas Robie to Mary (Robie) Sewall, 17 November 1788, Robie-Sewall Family Papers, MHS.

103 Thomas Robie to Mary (Robie) Sewall, 17 November 1788, Robie-Sewall Family Papers, MHS.

104 Mary (Robie) Sewall to Thomas Robie, 21 May 1789, Robie-Sewall Family Papers, MHS. 105 Mary Bradstreet Robie to Thomas Robie, 21 May 1789, Robie-Sewall Family Papers, MHS. 
almost all of Thomas Robie's interests now lay back in the United States. He landed in Portsmouth, New Hampshire, in the early weeks of June 1790. Long opposed to repatriation, upon arriving he echoed his wife's sentiments on the superiority of New England. "I can't be but took with the surprising contrast between New England and New Scotland," he said of initial impressions, and continued "For although the necessities of life were vastly lower [in Halifax], the difference is yet astonishingly great." For Robie, it was only after his return to New England that he recognized the folly of his past stubbornness. While he admitted he once held "a partiality" for Halifax, upon returning to New England he mocked the foolishness of the "hard inhabitants" of Nova Scotia and their insistence on building lives within the British Empire. ${ }^{106}$

\section{The Robie women and their continuing ties}

When news of Mary's engagement to Sewall reached her sister Hetty in Halifax, she shared none of her mother's excitement; instead, she lamented her own nuptial ties that bound her to Nova Scotia. "Those who did not extend their connections were the happiest," she wrote dejectedly to her mother. Describing the sadness she felt upon contemplating her sister's marriage, she explained "My tears flow as I write. I must take my leave. It is wrong to allow myself to dwell upon the subject." She also rhetorically asked "What shall I say upon the subject of losing my dearest sister?"107 When she learned her father would be leaving Halifax, too, Hetty was distraught. She noted that her family's removal back to New England was "a loss which I shall ever deprecate as one of the greatest in my life." ${ }^{108}$

In Massachusetts, both Mary Bradstreet Robie and her daughter took on more private lives than they had in Loyalist Halifax. Mary Bradstreet Robie replaced visiting strangers with long walks in her garden where she could observe "the beautiful presence of the trees in full bloom," and she noted a return to New England left her with "a grateful heart."109 Mary Sewall traded serving at the funerals of unknown refugees for a more domestic role caring for growing family. She grew increasingly focused on the household, especially organizing the hired staff, whom she described as "careless, dirty,

\footnotetext{
106 Thomas Robie to Mary Bradstreet Robie, 12 June 1790, Robie-Sewall Family Papers, MHS.

107 Mehetable (Robie) Sterns to Mary Bradstreet Robie, 6 September 1788, Robie-Sewall Family Papers, MHS.

108 Hetty Sterns to Mary Sewall, 26 October 1789, Robie-Sewall Family Papers, MHS. 109 Mary Bradstreet Robie to Thomas Robie, 24 May 1789, Robie-Sewall Family Papers, MHS.
} 
and lazy" without her supervision. Having removed herself from the hardware trade and immersed herself in the home, Mary took pride in her new role as mother. ${ }^{110}$ Her marriage to Sewall proved especially lucrative. Joseph went on to become a successful merchant and, later, treasurer for the Commonwealth of Massachusetts. The couple's second son, Samuel Edmund Sewall, had an even more distinguished career. He served in the Massachusetts Senate, helped found the Massachusetts Anti-Slavery Society in 1831, and was one of the first supporters of a small newspaper, The Liberator, which was run by friend and fellow abolitionist William Lloyd Garrison. ${ }^{111}$

The family's fortunes in Halifax were more mixed. After his studies with Sterns, Simon Bradstreet Robie established himself as a lawyer and became one of the leading politicians of the Loyalist faction in Nova Scotia. ${ }^{12}$ Hetty, on the other hand, only saw her hardships increase. A political rival savagely beat her husband to death in the streets of Halifax after a disagreement in $1798 .{ }^{113}$ To worsen matters, shortly after Sterns' death, Mary received word from Halifax that Hetty was both severely ill and advanced in pregnancy. Mary wrote to her grieving sister hoping she would join the family in New England. But ultimately she knew her sister would not join them as her "long residence at Halifax" created "a strong attachment" between her sister and their adoptive home. Hetty died in Halifax removed from her family. ${ }^{114}$

Only the youngest Robie continued to maintain relationships between New England and Nova Scotia into the 19nth century. Having never married, Hannah spent her life travelling between her brother's residences in Nova Scotia and her favorite nephew's home in Boston. ${ }^{115}$ Shortly before her death in

110 Mary (Robie) Sewall to Mary Bradstreet Robie, 13 February 1789, Robie-Sewall Family Papers, MHS.

111 On Samuel Edmund Sewall, see Richard Archer, Jim Crow North: The Struggle for Equal Rights in Antebellum New England (Oxford: Oxford University Press, 2007), 72 and Nina Moore Tiffany, Samuel E. Sewall: A Memoir (Cambridge, MA: Riverside Press, 1898).

112 Israel Longworth, "Hon. Simon Bradstreet Robie: A Biography," Collections of the Nova Scotia Historical Society 20 (1921): 1-15; J. Murray Beck, "Robie, Somon Bradstreet," DCB Online VIII, http://www.biographi.ca/.

113 On the disagreement between Sterns and Attorney-General Richard Uniacke, see Phyllis R. Blakeley, "Blowers, Sampson Salter," DCB Online VII, http://www.biographi.ca/.

114 Mary (Robie) Sewall to Joseph Sewall, 11 June 1798, Robie-Sewall Family Papers, MHS.

115 Hannah's travels between Boston and Nova Scotia exemplified the growing economic and cultural connection between New England and the Maritimes during the first half of the 18th century; see D.A. Sutherland, "Nova Scotia and the American Presence: Seeking Connections Without Conquest, 1848-1854," in New England and the Maritime Provinces: Connections and Comparisons, ed. Stephen J. Hornsby and John G. Reid (Montreal and Kingston: McGill-Queen's University Press, 2005), 144-58. 
1832, Mary Sewall scribbled a few words on the back of the diary she had kept nearly 50 years earlier in Halifax. She addressed the note to Hannah. Believing her time was short, Mary advised Hannah that while she could "show it to my children or Mr. Sewall," she would be better off burning the diary "as there is little worth preserving." ${ }^{\prime 16}$ As an itinerant living between both Massachusetts and Nova Scotia, however, Hannah found the account of the family's exile fascinating. As she read about her sister's life as a young adult in Halifax, she could not have helped but feel moved by the struggles the family faced.

As refugees in Halifax, the Robie women served important public roles. Not content to simply observe the suffering of other refugees, they embodied fellow feeling towards others as a sign of their refinement and for the greater public good. These were not simply imagined responsibilities; instead, acts and expressions of fellow feeling created a recognizable community of shared hardship in Loyalist Halifax. The Robie women also played an integral role in directing the fate of the family after the Revolution. Although they had followed the family patriarch into exile in 1775 , beginning in 1784 Mary Bradstreet Robie and her eldest daughter built their family's connections back to New England and eventually brought the majority of the Robie family home to Massachusetts.

The Robie women's compassionate actions while living as exiles in Halifax demonstrate the importance of Loyalist women to their communities and the centrality of shared suffering to refugee experience. But as Mary Bradstreet Robie's determination to bring her family back to New England reveals, the despair of Loyalist exile could also push some women to seek a return to their American homes. When her appeal to her husband's sensibilities failed, Robie established a more tangible connection back to Massachusetts through her daughter's marriage. Collectively, Mary Bradstreet Robie and her daughters' actions during their time as refugees suggest Loyalist women were not simply complicit followers. To the contrary, women had influence over their husband's decisions concerning the family and were also important public figures in the creation of Loyalist communities.

G. PATRICK O'BRIEN est professeur adjoint invité à I'Université Ave Maria. Ses recherches portent sur l'expérience des femmes et des familles loyalistes au cours de la Révolution américaine.

G. PATRICK O'BRIEN is a visiting assistant professor at Ave Maria University. His research examines the experience of Loyalist women and families during the American Revolution.

116 Mary Robie, diary, 1832, Robie-Sewall Family Papers, MHS. 